\title{
Microbiological quality of minimally processed vegetables commercialized in Brasilia, DF, Brazil
}

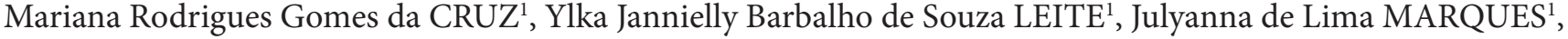 \\ Sabrina Lunara Santos PAVELQUESI ${ }^{1}$, Luana Ribeiro de Almeida OLIVEIRA ${ }^{1}$, \\ Izabel Cristina Rodrigues da SILVA ${ }^{1}$, Daniela Castilho ORSI ${ }^{1 *}$ (1D
}

\begin{abstract}
This study evaluated the microbiological quality of minimally processed vegetables commercialized in the city of Brasilia, DF, Brazil. A total of 32 samples of different vegetables were purchased from 10 supermarkets. In most samples (78.1\%) the populations of psychrotrophic bacteria had a high count ranging from $10^{6}$ to $10^{8} \mathrm{CFU} / \mathrm{g}$. Thermotolerant coliforms were found in all samples, with populations higher than $10^{2} \mathrm{MPN} / \mathrm{g}$ in 15 samples (46.9\%). After molecular analyses, E. coli was identified in 16 samples (50.0\%) and Salmonella spp. in 4 samples (12.5\%). S. aureus was found in 14 samples (43.8\%), with counts higher than $10^{3} \mathrm{CFU} / \mathrm{g}$ in 4 samples (12.5\%). The results obtained in this study showed that 16 samples (50\%) were unfit for consumption according to Brazilian legislation. These results indicated the need of adoption of better hygienic practices in the production of minimally processed vegetables to improve quality and microbiological safety.
\end{abstract}

Keywords: fresh vegetables; microbiological analyses; bacterial pathogens; food contamination; food safety.

Practical Application: Microbiological quality assessment of minimally processed vegetables marketed in the city of Brasilia.

\section{Introduction}

Fruits and vegetables are essential components of a human healthy diet and there are considerable evidences of the nutritional benefits associated with the regular consumption of fresh fruits and vegetables (Goodburn \& Wallace, 2013; Maffei et al., 2013). Consequently, nowadays, there is a growing interest in healthy diets, which increased consumption of vegetables and caused an expansion of the market for minimally processed vegetables. These products meet the needs of their consumers because of changes in the human lifestyle and its tendency to convenience and spending less time on preparing food (Gurler et al., 2015; Santos et al., 2012).

Minimally processed vegetables can be obtained from the fresh products through selection, washing, peeling, cutting or slicing, sanitization, rinsing, drying and packaging (Gurler et al., 2015; International Fresh-cut Produce Association, 2015; Tresseler et al., 2009). These products are defined as any fresh vegetable or combinations of them that has been physically altered from its original form, but remains in a fresh state, in order to preserve its nutritional and sensory properties (Cenci, 2011; International Fresh-cut Produce Association, 2015; Paula et al., 2009).

During processing, the mechanical damage caused to cells limits the shelf life of minimally processed vegetables. They are more susceptible to contamination because cutting and slicing damage the natural protective barriers of the intact vegetables and form exudates rich in nutrients that may support the growth of microorganisms. Because minimally processed vegetables are susceptible to spoilage, they must be kept refrigerated to $1-5^{\circ} \mathrm{C}$ for maintenance of freshness and quality (O'Beirne et al., 2014; Oliveira et al., 2011). Processors of fresh-cut produce and supermarket retailers work hard to ensure the products are always kept cold. The consumers should also keep the produce refrigerated when they bring it home. When the abuse in the cold chain occurs, it accelerates microbial growth and spoilage of the products. The variation of temperature in $5{ }^{\circ} \mathrm{C}$ may lead to doubling of growth rate of any foodborne pathogens contaminating these products (Cenci, 2011; International Fresh-cut Produce Association, 2015; Paula et al., 2009).

Minimally processed vegetables can be contaminated with foodborne pathogens via being exposed to contamination sources during agricultural production, harvesting and handling, minimal processing and by end-users after pack opening. The major sources of contamination are soil, water (animal or human faeces) and handling during pre or postharvest stages. The major sources of postharvest contamination are containers used for transporting the produce, human handling, processing and storage (Cenci, 2011; International Fresh-cut Produce Association, 2015; O'Beirne et al., 2014). Minimal processing operations, including anti-microbial treatments, cannot be relied upon to eliminate pathogens (Gurler et al., 2015; O’Beirne et al., 2014).

Minimally processed vegetables have become increasingly recognized as potential safety problem, since they are usually eaten raw, without washing or other decontamination procedures. The incidence of foodborne outbreaks caused by contaminated fresh vegetables has increased in recent years (Herman et al., 2015; 
Little \& Gillespie, 2008; Lynch et al., 2009). Several studies have isolated foodborne pathogens from raw vegetables, such as Salmonella spp. (Herman et al., 2015; Sant'Ana et al., 2011) and Escherichia coli (Herman et al., 2015; Söderström et al., 2008).

In Brazil, minimally processed vegetables are widely available, commercialized all year round and generally considered safe to eat by consumers. These vegetables can be stored for several days as minimally processed, since handled, packaged and refrigerated properly (Cenci, 2011; International Fresh-cut Produce Association, 2015; Sant'Ana et al., 2011). Therefore, the aim of this study was to evaluate the microbiological quality of minimally processed vegetables commercialized in supermarkets of Brasilia, DF, Brazil.

\section{Materials and methods}

\subsection{Samples and microbiological analyses}

Individual packs of 100-200 g of minimally processed vegetables (32 samples) belonging to different producers and different brands were collected from ten different supermarkets in the city of Brasilia, DF, Brazil, from December 2015 to July 2017. All the samples were obtained in the original package, within the shelf life of up to 6 days, as declared on labels. The samples were immediately transported to the laboratory in a cool box and microbiologically examined within $1 \mathrm{~h}$ of sampling. The samples were analyzed in triplicate and results were expressed as mean. The list of minimally processed vegetables types are shown in Table 1.

All the samples were analyzed for each of the following microorganisms or microbial groups: total mesophilic and psychrotrophic bacteria, total and thermotolerant coliforms, Staphylococcus aureus and Salmonella spp. An amount of $25 \mathrm{~g}$ of each sample was diluted in $225 \mathrm{~mL}$ of $0.1 \%$ peptone water. Samples were homogenized and an initial $10^{-1}$ dilution was obtained. Then, serial dilutions of the homogenates were prepared in $0.1 \%$ peptone water (up to $10^{-5}$ ).

For total mesophilic and psychrotrophic bacteria counts, serial dilutions of the samples were surface plated in Plate Count Agar (PCA) (HiMedia, USA), following incubation at $37^{\circ} \mathrm{C}$ for $24 \mathrm{~h}$ for mesophilic bacteria and $8-10^{\circ} \mathrm{C}$ for 7 days for psychrotrophic bacteria. The results were expressed by colony forming unit per gram $\left(\mathrm{CFU} \mathrm{g}{ }^{-1}\right)$. For detection of total and thermotolerant

Table 1. Composition and number of minimally processed vegetables samples analyzed in this study.

\begin{tabular}{lc}
\hline \multicolumn{1}{c}{ Composition } & $\begin{array}{c}\text { Number of } \\
\text { samples (\%) }\end{array}$ \\
\hline Sliced collard green (Brassica oleracea L.) & $13(40.6)$ \\
Salads $^{1)}$ & $7(21.9)$ \\
Sliced cabbage (Brassica oleracea L. var. Capitata) & $4(12.5)$ \\
Lettuce (Lactuca sativa L.) & $3(9.4)$ \\
Mix for yakisoba ${ }^{2)}$ & $3(9.4)$ \\
Alfalfa sprouts (Medicago sativa L) & $2(6.3)$ \\
\hline${ }^{1)}$ Composed by two or more of the following vegetables: lettuce (different varieties), \\
watercress, chard, cabbage, carrot, arugula and tomatoes; ${ }^{2)}$ Composed by cauliflower, \\
carrot, broccoli, cabbage and chard.
\end{tabular}

coliforms, one $\mathrm{mL}$ of each dilution was transferred to three-tube series containing Lauryl Sulfate Tryptose (LST) (HiMedia, USA) with Durhan tubes in its interior. Total coliforms were enumerated in Brilliant Green Bile Broth 2\% (HiMedia, USA), incubated at $37^{\circ} \mathrm{C}$ for $24 \mathrm{~h}$ and thermotolerant coliforms were determined in E. coli broth (EC) (Acumedia, USA) incubated at $45^{\circ} \mathrm{C}$ for $24 \mathrm{~h}$. The results were expressed by most probable number per gram $\left(\mathrm{MPN} \mathrm{g}^{-1}\right)$.

For total Staphylococcus aureus counts, serial dilutions of the samples were surface plated in Mannitol Salt Agar (HiMedia, USA), following incubation at $37^{\circ} \mathrm{C}$ for $48 \mathrm{~h}$. The colonies were counted and sub-cultured in Mannitol Salt Agar tubes. The characteristic colonies of Staphylococcus aureus (yellow colonies with yellow zones, mannitol-fermenting) stained by Gram's Method to confirm Gram-positive cocci. The colonies of $S$. aureus were further confirmed through molecular analyses.

The detection of Salmonella spp. was carried out with pre-enrichment in Lactose broth and incubation at $37^{\circ} \mathrm{C}$ for $24 \mathrm{~h}$. Subsequently, $1 \mathrm{~mL}$ of this medium was inoculated in Selenite Cystine and Tetrathionate broths (HiMedia, USA) that were incubated at $37^{\circ} \mathrm{C}$ for $24 \mathrm{~h}$. Further, Salmonella Shigella Agar (SS) and Xylose-Lysine Deoxycholate Agar (XLD agar) (HiMedia, USA) were streaked with sterile loops carrying inoculums took from Selenite cystine and Tetrathionate broths. The plates were incubated at $37^{\circ} \mathrm{C}$ for $24 \mathrm{~h}$ in order to isolate characteristic colonies of Salmonella spp. Triple sugar iron (TSI) (HiMedia, USA) was used for presumptive confirmation of colonies that were further confirmed through molecular analyses.

\subsection{Molecular analyses}

The potential pathogenic bacteria S. aureus, E. coli and Salmonella spp. were identified using the technique of polymerase chain reaction (PCR). For identification of S. aureus the primers SEC forward and reverse (Table 2) (Life Technologies, Brazil) specific for the staphylococcal enterotoxin C gene (SEC gene) were used. For identification of Salmonella spp. the primers InvA forward and reverse (Life Technologies, Brazil) (Table 1) specific for the invasion A gene (invA gene) were used. And for identification of $E$. coli the primers MalB forward and reverse (Life Technologies, Brazil) (Table 2) specific for the formation of acetaldehyde and ammonia from ethanolamine (MalB gene) were used.

For DNA extraction, the NucleoSpin Food" kit (Macherey-Nagel, Düren, Germany), was used, following the manufacturer's instructions. Extracted DNA was stored at $-20^{\circ} \mathrm{C}$. PCR was performed in a reaction mixture of $25 \mu$ final volume containing $2.5 \mu \mathrm{l}$ of PCR buffer; $0.7 \mu \mathrm{l}$ of $\mathrm{MgCl}_{2} ; 1.5 \mu \mathrm{L}$ of dNTP $(2,5 \mathrm{mM})$; $0.5 \mu \mathrm{l}$ of Taq DNA polymerase; $1.5 \mu \mathrm{L}$ of each primer forward and reverse and $18.3 \mu \mathrm{l}$ of Milli-Q water.

PCR amplification was performed with an initial denaturing step at $95^{\circ} \mathrm{C}$ for $1 \mathrm{~min}$, followed by a 35 -cycle reaction $\left(95^{\circ} \mathrm{C}\right.$ for $1 \mathrm{~min}$ and $60^{\circ} \mathrm{C}$ for $1 \mathrm{~min}$ ). A final extension step was undertaken at $72{ }^{\circ} \mathrm{C}$ for $1 \mathrm{~min}$. All thermal cycling reactions were performed with Techne TC-512 thermal cycler (Bibby Scientific Inc., USA). Both negative and reagent controls were included in each PCR run. The reagent control consisted of 
all PCR components except for the template DNA. All of the amplified DNA were separated by electrophoresis at $100 \mathrm{~V}$ for $50 \mathrm{~min}$ in $1.5 \%(\mathrm{w} / \mathrm{v})$ agarose gel and stained with ethidium bromide. Gels were visualized under UV light. A 100 bp DNA ladder was used as a molecular weight marker.

\section{Results and discussion}

Table 3 shows the counts of mesophilic and psychrotrophic bacteria $\left(\mathrm{CFU} \mathrm{g} \mathrm{g}^{-1}\right)$, enumeration of total and thermotolerant coliforms ( $\mathrm{MPN} \mathrm{g}^{-1}$ ) and counts of $S$. aureus $\left(\mathrm{CFU} \mathrm{g} \mathrm{g}^{-1}\right.$ ) in the samples of minimally processed vegetables. The populations of mesophilic and psychrotrophic bacteria in the tested samples were above $10^{4} \mathrm{CFU} \mathrm{g}{ }^{-1}$ and most samples had a high count ranging from $10^{6}$ to $10^{8} \mathrm{CFU} \mathrm{g}^{-1}$ (20 samples or $62.5 \%$ for mesophilic bacteria and 25 samples or $78.1 \%$ for psychrotrophic bacteria). Although microbial loads tend to be higher for fresh vegetables (Maffei et al., 2013), a reduction of the microbial load is expected after its sanitization (Internacional Comission on Microbiological Specifications for Foods, 2002). Some of these bacteria can grow during storage, especially those that are psychrotrophic and when packaged products are not stored at the temperature (usually between $5{ }^{\circ} \mathrm{C}$ ) recommended by the provider products (Cenci, 2011; International Fresh-cut Produce Association, 2015).

Oliveira et al. (2011) also reported high populations of psychrotrophic bacteria (average populations of $10^{7}-10^{9} \mathrm{CFU} \mathrm{g}^{-1}$ ) in 162 samples of minimally processed vegetables $(100 \%$ of analyzed samples) acquired from supermarkets in the city of Ribeirão Preto, São Paulo, Brazil. Similarly, Santos et al. (2012) found psychrotrophic bacteria count $>10^{6} \mathrm{CFU} \mathrm{g}^{-1}$ in 108 salads (71.47\% of analyzed samples) commercialized in Portugal.
Generally, mesophilic and psychrotrophic bacteria counts and enumeration of total coliforms are useful for indicating the shelf-life duration and microbial quality of foods (Internacional Comission on Microbiological Specifications for Foods, 2002). According to Oliveira et al. (2011) high populations of psychrotrophic bacteria suggesting a short shelf life for the product and poor hygienic quality, likely due to the use of highly contaminated raw material, lack of good hygienic practices during processing and/or inadequate temperature of storage.

Most samples of minimally processed vegetables (22 samples or $68.8 \%$ of analyzed samples) had enumeration of total coliforms higher than $10^{3} \mathrm{MPN} \mathrm{g}^{-1}$. Similarly, Oliveira et al. (2011) reported the majority of samples of minimally processed vegetables (132 samples or $81.5 \%$ of analyzed samples) sold in supermarkets in the city of Ribeirão Preto with populations above $10^{3} \mathrm{MPN} \mathrm{g}^{-1}$ for total coliforms. Silva et al. (2007) also reported high counts of total coliforms $\left(>10^{3} \mathrm{MPN} \mathrm{g}^{-1}\right)$ for the 28 samples of minimally processed vegetables sold in supermarkets in the city of Porto Alegre.

In this study, thermotolerant coliforms were found in all samples of minimally processed vegetables, with populations higher than $10^{2} \mathrm{MPN} \mathrm{g}^{-1}$ in 15 samples (46.9\%). The maximum value allowed by the Brazilian legislation for thermotolerant coliforms is $10^{2} \mathrm{MPN} \mathrm{g}^{-1}$ for fresh vegetables (Brasil, 2001). Thermotolerant coliforms may efficiently indicate failures in sanitization process, because they are associated with fecal contamination and they can indicate potential contamination by enteric pathogens (Paula et al., 2009; Silva et al., 2007).

Oliveira et al. (2011) reported that $45.6 \%$ of the samples analyzed (74 samples out of a total of 162) of minimally processed vegetables sold in supermarkets in the city of Ribeirão Preto exceeded the acceptable limit for thermotolerant coliforms of

Table 2. Primers sequence and size of amplified products of PCR.

\begin{tabular}{llcc}
\hline \multicolumn{1}{c}{ Primer } & \multicolumn{1}{c}{ Sequence 5' $^{\prime}$ - ${ }^{\prime}$ Amplified product } & Bacteria \\
\hline SEC-foward & TTTTACACCCAACGTATTAGCAGA & $401 \mathrm{bp}$ & S. aureus \\
SEC-reverse & TCCCATTATCAAAGTGGTTTCC & & Salmonella spp. \\
InvA-foward & GCTGATGCCGGTGAAATTAT & $445 \mathrm{bp}$ & E. coli \\
InvA-reverse & CGACAAGACCATCACCAATG & & $113 \mathrm{bp}$ \\
MalB-foward & TCTATGGGCTGTGACTGCTG & & \\
MalB-reverse & GGCATCCCCATGATGTAGTT & & \\
\hline
\end{tabular}

Table 3. Prevalence of microbial counts in the samples of minimally processed vegetables.

\begin{tabular}{|c|c|c|c|c|c|}
\hline Count interval ${ }^{a}$ & $\begin{array}{c}\text { Mesophilic } \\
\text { Bacteria } \\
\mathrm{n}(\%) \\
\end{array}$ & $\begin{array}{c}\text { Psychrotrophic } \\
\text { bacteria } \\
\text { n (\%) }\end{array}$ & $\begin{array}{l}\text { Total coliforms } \\
\text { n (\%) }\end{array}$ & $\begin{array}{c}\text { Thermotolerant } \\
\text { coliforms } \\
\mathrm{n}(\%)\end{array}$ & $\begin{array}{c}\text { S. aureus } \\
\text { n (\%) }\end{array}$ \\
\hline ND & - & - & - & - & $18(56.3)$ \\
\hline $10^{1}-10^{2}$ & - & - & $3(9.38)$ & $17(53.1)$ & $2(6,25)$ \\
\hline $10^{2}-10^{3}$ & - & - & 7 (21.9) & $11(34.4)$ & $8(25.0)$ \\
\hline $10^{3}-10^{4}$ & - & - & $22(68.8)$ & $4(12.5)$ & $3(9.38)$ \\
\hline $10^{4}-10^{5}$ & 7 (21.9) & $2(6.25)$ & - & - & $1(3.12)$ \\
\hline $10^{5}-10^{6}$ & $5(15.6)$ & $5(15.6)$ & - & - & - \\
\hline $10^{6}-10^{7}$ & $7(21.9)$ & $12(37.5)$ & - & - & - \\
\hline $10^{7}-10^{8}$ & $13(40.6)$ & $13(40.6)$ & - & - & - \\
\hline
\end{tabular}

Count interval $^{\mathrm{a}}=$ expressed in $\mathrm{CFU} \mathrm{g}^{-1}$ or $_{\mathrm{MPN} \mathrm{g}}{ }^{-1} ; \mathrm{n}(\%)=$ number and percentage of positive samples; ND = not detected. 
$10^{2} \mathrm{MPN} \mathrm{g}^{-1}$. Paula et al. (2009) reported that $87.5 \%$ of the samples analyzed (42 samples out of a total of 48) of minimally processed vegetables (spinach, green beans, pumpkin and lettuce) sold in supermarkets in the city of Brasília, DF, Brazil, had populations of thermotolerant coliforms above $10^{2} \mathrm{MPN} \cdot \mathrm{g}^{-1}$.

After molecular analyses, E. coli was found in 16 samples (50.0\%) (Table 4). Oliveira et al. (2011) detected E. coli in 53.1\% of the samples of minimally processed vegetables commercialized in city of Ribeirão Preto and Silva et al. (2007) detected E. coli in 8 samples $(28.6 \%)$ of minimally processed vegetables commercialized in city of Porto Alegre.

The polymerase chain reaction (PCR) was used to amplify DNA sequences from the MalB gene of Escherichia coli. The MalB gene is specific for the formation of acetaldehyde and ammonia from ethanolamine. Candrian et al. (1991) used the MalB gene to detection of $E$. coli strains obtained from samples of Swiss-ltalian soft cheese made from unpasteurized milk. Wang et al. (1997) also used the gene MalB to detection of $E$. coli in seafood samples. All $E$. coli strains tested yielded the specific DNA fragment (MalB gene) and no amplification products were obtained with other Enterobacteriaceae tested (Enterobacter spp., Samonella spp. and Yersinia enterocolitica).

In this study, Salmonella spp. was detected and confirmed by PCR in 4 samples (12.5\%) (Table 4). According to Brazilian legislation (Brasil, 2001), the presence of Salmonella in fresh vegetables is unacceptable (absence/25 $\mathrm{g}$ ) and may represent a risk for consumers. The contamination rate of the samples from this study was higher than that observed by Oliveira et al. (2011) who found only 2 samples (1.2\%) of minimally processed vegetables contaminated with Salmonella spp. Nguz et al. (2005) reported similar results and found an incidence of $13.3 \%$ of samples (8 samples out of a total of 60) of fresh mixed cut vegetables produced in Zambia contaminated with Salmonella spp. Gurler et al. (2015) reported 8 samples of mediterranean salads (14\%) and 6 samples of sezar salads (12\%) contaminated with Salmonella spp. These samples were collected from different restaurants, cafes and supermarkets in Turkey.

The pathogenic Salmonella spp. strains were identified by PCR used to amplify DNA sequences from the InvA gene. Salmonella pathogenicity depends on a variety of virulence factors that help the pathogen in adhesion and invasion mechanisms. Invasion gene (invA) exists in the majority of Salmonella strains and is related to intestinal mucosa invasion (Chuanchuen et al., 2010; Fluit, 2005).
Foodborne diseases caused by Salmonella spp. and E. coli are usually associated with the consumption of animal products or cross-contamination by animal products. Contamination of vegetables with bacterial pathogens like E. coli and Salmonella can happen by animal manure used for fertilizer, water used for irrigation and animals that traverse vegetable fields. Contamination can also occur during processing (Herman et al., 2015; Nguz et al., 2005). Therefore, the potential contamination of vegetables by E. coli and Salmonella should be considered as these bacterial pathogens can survive and be internalized into plant tissues, rendering many disinfection treatments ineffective (Herman et al., 2015; O'Beirne et al., 2014).

According to Herman et al. (2015) during 1973-2012 in USA, 606 foodborne diseases and outbreaks had a leafy vegetable implicated (162 outbreaks with a simple leafy vegetable as the vehicle and 444 outbreaks with a leafy vegetable-based salad as the vehicle). The bacteria pathogens that most often caused leafy vegetable-associated outbreaks were Shiga toxin-producing Escherichia coli (STEC) and Salmonella. The STEC serogroup that majority caused the outbreaks was O157 (45 outbreaks, $94 \%$ of confirmed STEC outbreaks).

In this study, Staphylococcus aureus was found in 14 samples $(43.8 \%)$ of minimally processed vegetables, with counts higher than $10^{3} \mathrm{CFU} \mathrm{g}^{-1}$ in 4 samples (12.5\%) (Table 3). The maximum value allowed by the Brazilian legislation for S. aureus is $10^{3} \mathrm{CFU}$ $\mathrm{g}^{-1}$ for fresh vegetables (Brasil, 2001). After molecular analyses, $S$. aureus producing the enterotoxin $C$ gene was identified in 13 samples (Table 4). Nguz et al. (2005) reported an incidence of $60 \%$ (12 samples out of a total of 20) of S. aureus in fresh-cut mixed vegetables produced in Zambia. Seo et al. (2010) found an overall incidence of $11.3 \%$ of $S$. aureus in the 355 analyzed samples of minimally processed vegetables in Korea. At least 13 of 129 mixed salads samples (10.1\%) and 19 of 112 sprouts (broccoli, alfalfa, clover and soybean) samples (17.0\%) were contaminated with $S$. aureus.

The growth of $S$. aureus in food produces several enterotoxins that cause nausea, vomiting and diarrhea in consumers. Staphylococcal food poisoning is dependent on levels of toxin produced by S. aureus during growth. Staphylococcal enterotoxins (SEs) are a group of heatstable, pepsin-resistant enterotoxins belonging to a large family of pyrogenic toxin super-antigens encoded by phage (SEA), chromosome (SEB and SEC) or plasmid genes (SED) (Argudín et al., 2010; Seo et al., 2010). Enterotoxin C (SEC) is divided into subtypes $\mathrm{C} 1, \mathrm{C} 2$ and $\mathrm{C} 3$ and is an important cause of foodborne intoxication (Tamarapu et al., 2001).

Table 4. Occurrence of E. coli, S. aureus and Salmonella spp. in samples of minimally processed vegetables after PCR.

\begin{tabular}{lcccc}
\hline \multicolumn{1}{c}{ Sample } & Total of samples & E. coli & Salmonella spp. & S. aureus \\
\hline Sliced collard green & 13 & 7 & 3 & 5 \\
Salad & 7 & 5 & - & 1 \\
Sliced cabbage & 4 & 1 & - & 2 \\
Lettuce & 3 & 1 & - & - \\
Mix for yakisoba & 3 & 1 & - & - \\
Alfalfa Sprouts & 2 & 1 & 4 & 1 \\
Total & 32 & 16 & & 13 \\
\hline
\end{tabular}


Table 5. Samples of minimally processed vegetables unfit for consumption.

\begin{tabular}{|c|c|c|c|c|}
\hline Microorganisms above the limit* and/or presence of Salmonella & $\begin{array}{c}\text { Sliced collard } \\
\text { green }\end{array}$ & Salad & Sliced cabbage & Mix for yakisoba \\
\hline Thermotolerant coliforms & 4 & 3 & 2 & 1 \\
\hline Thermotolerant coliforms and Salmonella spp. & 2 & - & - & - \\
\hline S. aureus and Salmonella spp. & - & - & 1 & - \\
\hline Thermotolerant coliforms, S. aureus and Salmonella spp. & 1 & - & - & - \\
\hline Thermotolerant coliforms and S. aureus & 2 & - & - & - \\
\hline Total & 9 & 3 & 3 & 1 \\
\hline
\end{tabular}

*according to Brazilian legislation: Thermotolerant coliforms $>10^{2} \mathrm{MPN} \mathrm{g}^{-1}$, S. aureus $>10^{3} \mathrm{CFU} \mathrm{g}^{-1}$ and presence of Salmonella spp.

It is important to note that in case of minimally processed vegetables, $S$. aureus is a pathogen known to be carried mainly by food handlers and therefore good hygiene practices must be implemented by producers and processors in order to prevent S. aureus contamination. Staphylococcus aureus is a bacterium ubiquitously distributed in the environment and can be found on the skin and in the noses of up to $25 \%$ of healthy people and animals. The major route of transmission of $S$. aureus to food is through direct contacts with food handlers carrying the bacterium. S. aureus does not compete well with indigenous microflora in raw vegetables. However, $S$. aureus can grow in processed foods contaminated during preparation and storage under temperature-abused conditions (Argudín et al., 2010; Seo et al., 2010; Tamarapu et al., 2001).

The results obtained in this study showed that 16 samples (50\%) were unfit for consumption according to Brazilian legislation (Table 5). Some samples presented more than one group of potentially pathogenic microorganisms such as a sample of collard green with presence of Salmonella, excess of thermotolerant coliforms and S. aureus, representing greater risk to consumer health.

\section{Conclusion}

In conclusion, this study showed that minimally processed vegetables may contain pathogenic bacteria and therefore could represent a risk to the consumers. A total of 32 samples were analyzed and the results showed that 16 samples (50\%) were unfit for consumption according to Brazilian legislation. Good hygiene practices must be implemented by producers in order to minimize the risks of transmission of foodborne pathogens. Supermarket retailers and consumers must also guarantee that refrigerated conditions are always maintained.

\section{References}

Argudín, M. Á., Mendoza, M. C., \& Rodicio, M. R. (2010). Food poisoning and Staphylococcus aureus enterotoxins. Toxins, 2(7), 1751-1773. http://dx.doi.org/10.3390/toxins2071751. PMid:22069659.

Brasil. Agência Nacional de Vigilância Sanitária. (2001, Janeiro 2). Aprova padrões microbiológicos para alimentos (Resolução no 12 , de 2 de janeiro de 2001). Diário Oficial [da] República Federativa do Brasil.

Candrian, U., Furrer, B., Höfelein, C., Meyer, R., Jermini, M., \& Lüthy, J. (1991). Detection of Escherichia coli and identification of enterotoxigenic strains by primer-directed enzymatic amplification of specific DNA sequences. International Journal of Food Microbiology,
12(4), 339-351. http://dx.doi.org/10.1016/0168-1605(91)90148-I. PMid:1854602.

Cenci, S. A. Processamento mínimo de frutas e hortaliças: tecnologia, qualidade e sistemas de embalagem. (2011) Rio de Janeiro: Embrapa.

Chuanchuen, R., Ajariyakhajorn, K., Koowatananukul, C., Wannaprasat, W., Khemtong, S., \& Samngamnim, S. (2010). Antimicrobial resistance and virulence genes in Salmonella enterica isolates from dairy cows. Foodborne Pathogens and Disease, 7(1), 63-69. http:// dx.doi.org/10.1089/fpd.2009.0341. PMid:19821743.

Fluit, A. C. (2005). Towards more virulent and antibiotic-resistant Salmonella? FEMS Immunology and Medical Microbiology, 43(1), 1-11.http://dx.doi.org/10.1016/j.femsim.2004.10.007. PMid:15607630.

Goodburn, C., \& Wallace, C. A. (2013). The microbiological efficacy of decontamination methodologies for fresh produce: A review. Food Control, 32(2), 418-427. http://dx.doi.org/10.1016/j.foodcont.2012.12.012.

Gurler, Z., Pamuk, S., Yildirim, Y., \& Ertas, N. (2015). The microbiological quality of ready-to-eat salads in Turkey: A focus on Salmonella spp. and Listeria monocytogenes. International Journal of Food Microbiology, 196, 79-83. http://dx.doi.org/10.1016/j.ijfoodmicro.2014.11.021. PMid:25528536.

Herman, K. M., Hall, A. J., \& Gould, L. H. (2015). Outbreaks attributed to fresh leafy vegetables, United States, 1973-2012. Epidemiology and Infection, 143(14), 3021-3020. http://dx.doi.org/10.1017/ S0950268815000047. PMid:25697407.

Internacional Comission on Microbiological Specifications for Foods - ICMSF. (2002). Microrganisms in Foods 7: Microbiological testing in food safety management. New York: Kluwer Academic.

International Fresh-cut Produce Association - IFPA. (2015). Alexandria: IFPA. Retrieved from http://www.fresh-cuts.org

Little, C. L., \& Gillespie, I. A. (2008). Prepared salads and public health. Journal of Applied Microbiology, 105(6), 1729-1743. http://dx.doi. org/10.1111/j.1365-2672.2008.03801.x. PMid:18397258.

Lynch, M. F., Tauxe, R. V., \& Hedberg, C. W. (2009). The growing burden of foodborne outbreaks due to contaminated fresh produce: risks and opportunities. Epidemiology and Infection, 137(3), 307-315. http://dx.doi.org/10.1017/S0950268808001969. PMid:19200406.

Maffei, D. F., Silveira, N. F. A., \& Catanozi, M. P. L. M. (2013). Microbiological quality of organic and conventional vegetables sold in Brazil. Food Control, 29(1), 226-230. http://dx.doi.org/10.1016/j. foodcont.2012.06.013.

Nguz, K., Shindano, J., Samapundo, S., \& Huyghebaert, A. (2005). Microbiological evaluation of fresh-cut organic vegetables produced in Zambia. Food Control, 16(7), 623-628. http://dx.doi.org/10.1016/j. foodcont.2004.07.001.

O’Beirne, D., Gleeson, E., Auty, M., \& Jordan, K. (2014). Effects of processing and storage variables on penetration and survival of 
Escherichia coli O157:H7 in fresh-cut packaged carrots. Food Control, 40, 71-77. http://dx.doi.org/10.1016/j.foodcont.2013.11.026.

Oliveira, M. A., Maciel de Souza, V., Morato Bergamini, A. M., \& De Martinis, E. C. P. (2011). Microbiological quality of ready-to-eat minimally processed vegetables consumed in Brazil. Food Control, 22(8), 1400-1403. http://dx.doi.org/10.1016/j.foodcont.2011.02.020.

Paula, N. R. F., Vilas Boas, E. V. B., Rodrigues, L. J., Carvalho, R. A., \& Piccoli, R. H. (2009). Qualidade de produtos minimamente processados e comercializados em gôndolas de supermercados nas cidades de Lavras - MG, Brasília - DF e São Paulo - SP. Ciência e Agrotecnologia, 33(1), 219-227. http://dx.doi.org/10.1590/S141370542009000100031.

Sant'Ana, A. S., Landgraf, M., Destro, M. T., \& Franco, B. D. G. M. (2011). Prevalence and counts of Salmonella spp. in minimally processed vegetables in Sao Paulo, Brazil. Food Microbiology, 28(6), 12351237. http://dx.doi.org/10.1016/j.fm.2011.04.002. PMid:21645825.

Santos, M. I., Cavaco, A., Gouveia, J., Novais, M. R., Nogueira, P. J., Pedroso, L., \& Ferreira, M. (2012). Evaluation of minimally processed salads commercialized in Portugal. Food Control, 23(1), 275-281. http://dx.doi.org/10.1016/j.foodcont.2011.06.022.

Seo, Y. H., Jang, J. H., \& Moon, K. D. (2010). Occurrence and characterization of enterotoxigenica Staphylococcus aureus isolated from minimally processed vegetables and sprouts in Korea. Food Science and Biotechnology, 19(2), 313-319. http://dx.doi.org/10.1007/ s10068-010-0045-7.
Silva, R. P. S., Verdin, S. E. F., Pereira, D. C., Schatkoski, A. M., Rott, M. B., \& Corção, G. (2007). Microbiological quality of minimally processed vegetables sold in Porto Alegre, Brazil. Brazilian Journal of Microbiology, 389(4), 594-598. http://dx.doi.org/10.1590/S151783822007000400003 .

Söderström, A., Osterberg, P., Lindqvist, A., Jönsson, B., Lindberg, A., Blide Ulander, S., Welinder-Olsson, C., Löfdahl, S., Kaijser, B., De Jong, B., Kühlmann-Berenzon, S., Boqvist, S., Eriksson, E., Szanto, E., Andersson, S., Allestam, G., Hedenström, I., Ledet Muller, L., \& Andersson, Y. (2008). A larger Escherichia coli O157:H7 outbreak in Sweden associated with locally produced lettuce. Foodborne Pathogens and Disease, 5(3), 339-349. http://dx.doi.org/10.1089/ fpd.2007.0065. PMid:18767979.

Tamarapu, S., Mckillip, J. L., \& Drake, M. (2001). Development of a multiplex polymerase chain reaction assay for detection and differentiation of Staphylococcus aureus in dairy products. Journal of Food Protection, 64(5), 664-668. http://dx.doi.org/10.4315/0362028X-64.5.664. PMid:11347997.

Tresseler, J. K., Figueiredo, E. A. T., Figueiredo, R. W., Machado, T. F., Delfino, C. M., \& Sousa, P. H. M. (2009). Avaliação da qualidade microbiológica de hortaliças minimamente processadas. Ciência e Agrotecnologia, 33(spe), 1722-1727. http://dx.doi.org/10.1590/ S1413-70542009000700004.

Wang, R. F., Cao, W. W., \& Cerniglia, C. E. (1997). A universal protocol for PCR detection of 13 species of foodborne pathogens in foods. Journal of Applied Microbiology, 83(6), 727-736. http://dx.doi. org/10.1046/j.1365-2672.1997.00300.x. PMid:9449811. 